\title{
EFFECT OF CAPITAL ADEQUACY, LIQUIDITY AND OPERATIONAL EFFICIENCY TO PROFITABILITY IN BANK SYARIAH MANDIRI (Period 2008 s.d. 2015)
}

\author{
Ismaulina dan Zulfadhli \\ Jurusan Syariah STAIN Malikussaleh Lhokseumawe \\ Jl. Medan Banda Aceh Km. 275, No. Buket Rate-Alue Awe, Lhokseumawe \\ e-mail: ismaulina@gmail.com dan fadli_z58@yahoo.com
}

\begin{abstract}
This research aimed at analyzing the effects of Capital Adequacy (CAR), liquidity (FDR) and operational efficiency (BOPO) toward profitability (ROA) in PT. Bank Syariah Mandiri (2008 to 2015 Period). The effects of CAR, FDR and BOPO were measured quantitatively and correlated to the company's ROA by means of double linear regression formula. The object of the research was three-monthly financial report through 31 observations. The findings showed that $C A R$ and BOPO had negative and significant effects toward ROA. FDR had positive and no significant effects toward $R O A$. It was found that $94.6 \%$ of $\mathrm{RO} A$ could be explained by the variables of $C A R, F D R$ and BOPO, while $5.4 \%$ could be explained by other variables which were not included in this research.
\end{abstract}

Kata kunci: kecukupan modal (CAR), likuiditas (FDR), efisiensi operasi (BOPO) dan profitabilitas (ROA)

\section{INTRODUCTION}

I Islamic banks as a financial better performance compared to the bank on the basis of interest. The merit description of an Islamic bank can be recognized by its performance and changes in financial position of banks operating activities that are useful in decision making (Muhammad, 2005: 251). The development of Islamic banking is very rapid. The rapid growth was recorded since Bank Indonesia issued the new regulation that gave permission for the opening of new Islamic banks as well as the establishment of Sharia (UUS). Furthermore, it was a clear evidence when the economic crisis hit Indonesia in the mid of 1997, that the bank operating within Islamic principles could survive amid the turmoil of the exchange rate and interest rates were high. In 1999 Bank Syariah Mandiri (BSM) became the second Islamic Banks which was a conversion of the Bank Susila Bakti.

The performance of BSM as an Islamic bank which is a conversion from a conventional bank, shows such a proud improvement. It can be seen from the financial performances, such as the capital (CAR), liquidity (FDR), operational efficiency (ROA), profitability (ROA), and financial ratios sharing. Table 1.1 presents financial development ratios of Bank Syariah Mandiri based on financial statements. 
Table 1.

Data Financial Ratios PT. Bank Syariah Mandiri (\%)

\begin{tabular}{|l|c|c|c|c|}
\hline \multirow{2}{*}{\multicolumn{1}{c|}{ Rasio }} & \multicolumn{4}{c|}{ Tahun } \\
\cline { 2 - 5 } & $\mathbf{2 0 1 1}$ & $\mathbf{2 0 1 2}$ & $\mathbf{2 0 1 3}$ & $\mathbf{2 0 1 4}$ \\
\hline CAR & 14.57 & 13.82 & 14,10 & 14,76 \\
\hline FDR & 86.03 & 94.40 & 89.37 & 82,13 \\
\hline BOPO & 76.64 & 73.00 & 84.03 & 98,49 \\
\hline ROA & 1.95 & 2.25 & 1,53 & 0,17 \\
\hline
\end{tabular}

Source: Data Condensed Financial Statements PT. Bank Syariah Mandiri

According to the provisions of bank Indonesia, the minimum CAR requirement for banks is $8 \%$. That indicates Bank Syariah Mandiri has good capital adequacy, as seen in the table above. Good capital adequacy was used as supporting assets that contain risks, such as financing provided. The FDR of Bank Syariah Mandiri always in the average standard of BI for the liquidity that is 85$110 \%$. This shows that during the above period PT. Bank Syariah Mandiri is able to compensate for the provision of financing to customers who require cost by the demand of depositors who want to withdraw the money that has been used by banks to provide financing. ROA ratio of PT. Bank Syariah Mandiri in 2011-2013 was included into healthy category set by $\mathrm{BI}$ is $\leq 93.52 \%$ and in 2014 BOPO of Bank Syariah Mandiri reached to $98.49 \%$ which is under the terms of BI categorized less healthy (> $94.72-95.92 \leq \%)$.

ROA of Bank Syariah Mandiri from the table above shows amounted to $1.95 \%$, in 2011 rose to $2.25 \%$ in 2012 , but fell back to $1.53 \%$ in 2013 and decreased to $0,17 \%$ in 2014. The greater ROA, the greater profit level reached by bank, thus position of bank in terms of asset utilization become better. In terms of assets management, the objectives must be consider, such as liquidity, safety, and income (profitability). Furthermore, fund management require prudential supervision to control the risks from bank activities, thus the bank becoming safe and healthy, as well as support the security and health of the banking system (Permadi Gandrapradja, 2004: 34). To assess whether a bank is healthy, an approach called CAMEL which stands for capital, assets, management, earnings and liquidity is employed in many countries.

To ascertain whether the quality of the bank is safe and healthy, the assessment carried out in qualitatievely and quantitatively using CAMEL approach, in line with the conditions set out in prudential regulation. In essence, the capital invested by is to make profit. This is the most capital factor determining the profits of banks. The level of public trust for the bank is strongly influenced by the bank's ability to pay its obligations immediately due and the ability to provide loans (loan) needed by the community (Julius R. Latumaerissa, 2005: 129). The level of capital adequacy is an extremely important point to note, because the level of capital adequacy reflects the bank's ability to bear the risk of loss that may arise. High capital will increase cash reserves that can be used to extend the financing, expanding the office network as well as providing modern 
office facilities and sophisticated telecommunications systems, thus open up greater opportunities to improve the profitability of banks.

The level of liquidity is inversely proportional to the level of profitability; when the high bank liquidity, the profitability is low, and conversely, when liquidity is low then profitability is high. The greater the ability of banks to channel financing, the greater the chance of the bank to earn profits, yet the expansion of financing can reduce the level of bank liquidity. This is difficult for bankers to manage liquidity and profitability since ancient dilemma banking world because it is always conflicting interests. To achieve the expected level of profitability, it is necessary to pursue various efforts and strategies to support the achievement of the optimal level of bank health. One of them is by re-establishing the banking capital structure that aligns the business scale and capital requirement as increasing the capacity to absorb business risk, and increased its operational efficiency so as to encourage the profitability to a higher level.

The ratio of Operating Expenses to Operating Income (ROA) shows the bank's efficiency in running the business substantially, especially financing, where until now the income of banks in Indonesia is still dominated by financing income. The smaller the bank's ROA indicates more efficient in carrying out its business activities. The higher the income, the bank charges to be inefficient so that the Return on Assets (ROA) is smaller. In other words, BOPO negatively related to the performance of the bank so that it is predicted also negatively affect the ROA. ROA focus on the company's ability to obtain earnings in the company's operations. Thus, in this study ROA is used as a measure of corporate performance. The reason for choosing ROA as a measure of performance is due to the use of ROA to measure the effectiveness of the company in generating profits by exploiting its assets. Based on the above elucidation, the author was interested in doing research on the effect of capital adequacy ratio (CAR), liquidity (FDR), and operational efficiency (ROA) to profitability (ROA) at PT. Bank Syariah Mandiri, Tbk. (in the period of 2008 up to 2015). "

\section{FORMULATION OF THE PROBLEM}

Based on the description above, the formulation of the problem in this study can be described as follows:

1. Is the Capital Adequacy Ratio (CAR) effect on profitability at PT. Bank Syariah Mandiri (in the period of 2008 up to 2015)?

2. Do Financing to Deposit Ratio (FDR) effect on profitability at PT. Bank Syariah Mandiri (in the period of 2008 up to 2015)?

3. Is Operating Expense to Operating Income (BOPO) effect on profitability at PT. Bank Syariah Mandiri (in the period of 2008 up to 2015)?

4. Do simultaneously Capital Adequacy Ratio (CAR), Financing to Deposit Ratio (FDR) and Operating Expense to Operating Income (BOPO) effect on profitability at PT. Bank Syariah Mandiri (in the period of 2008 up to 2015)? 


\section{RESEARCH PURPOSES}

The purpose of this study are as follows:

1. To determine the effect of the Capital Adequacy Ratio (CAR) on profitability at PT. Bank Syariah Mandiri (in the period of 2008 up to 2015).

2. To determine the influence of Financing to Deposit Ratio (FDR) on profitability at PT. Bank Syariah Mandiri (in the period of 2008 up to 2015).

3. To determine the influence of Operating Expense to Operating Income (BOPO) on profitability at PT. Bank Syariah Mandiri (in the period of 2008 up to 2015).

4. To determine whether simultaneous Capital Adequacy Ratio (CAR), Financing to Deposit Ratio (FDR) and Operating Expense to Operating Income (BOPO) effect on profitability at PT. Bank Syariah Mandiri (in the period of 2008 up to 2015).

\section{HYPOTHESIS}

The hypothesis to be tested in this study are:

1. $\mathrm{HI}_{1}=$ There was a positive and significant impact on CAR on profitability.

2. $\mathrm{HI}_{2}=$ There was a positive and significant influence on the FDR on profitability.

3. $\mathrm{HI}_{3}=$ There was a negative and significant effect on $\mathrm{BOPO}$ on profitability.

4. $\mathrm{HI}_{4}=$ There was a significant effect simultaneously CAR, FDR and ROA to profitability.

\section{RESEARCH METHODS}

This research was a quantitative research. The source of the data used in this study presented were a CAR ratio, ratio (FDR), the ratio (BOPO) and $\mathrm{ROA}$ ratio at PT. Bank Syariah Mandiri, which werer obtained from quarterly financial reports through the official website of Bank Syariah Mandiri (http://www.syariah mandiri.co.id) starting from March 2008 up to September 2015 with a total of 31 samples observed. In this study, the dependent variable $(Y)$ was the ratio of profitability ROA while the independent variable $(X)$ in this study were: CAR $(X 1)$; FDR (X2); BOPO (X3). This study used regression time-series cross-section (pooled regression). Tools such as multiple linear regression analysis test were conducted prior to the classical assumptions. Multiple linear regression equation in this study are as follows:

$$
\begin{aligned}
& \mathrm{Y}=\mathrm{a}+\mathrm{b} 1 \mathrm{X} 1+\mathrm{b} 2 \mathrm{X} 2+\mathrm{b} 3 \mathrm{X} 3+\mathrm{e} \\
& \text { Where the dependent variable is: } \\
& \mathrm{Y} \quad=\text { Return on Assets (ROA) } \\
& \text { While the Independent variables are: } \\
& \mathrm{X} 1 \quad=\text { CAR; } \\
& \mathrm{X} 2 \quad=\text { FDR; } \\
& \mathrm{X} 3 \quad=\text { BOPO } \\
& \begin{array}{ll}
\mathrm{a} & =\text { Value intercept (constant) } \\
\mathrm{b} 1-\mathrm{b} 2-\mathrm{b} 3 & =\text { coefficient regression direction } \\
\mathrm{e} & =\text { Variable disorder }
\end{array}
\end{aligned}
$$

Hypothesis Testing performed using Significance Tests Persia (T-test) and Significance Simultaneous (F-test) as well as the coefficient of determination (R2).

\section{THEORETICAL BASIS}

\section{Definition of Capital Adequacy}

Capital also has multiple functions in banking, among others are: (1) to protect the depositors who are not insured, at the time of a state bank and liquidation insolvable, (2) to absorb unexpected losses in order to maintain public confidence that the bank can continue to operate, (3) 
to obtain physical suggestion fund other basic needs required to offer bank services, and (4) as a means of implementing regulations for asset expansion control that is not appropriate (Rachmadi Usman, 2001: 113-114). In order to obtain optimal results, banks are required to manage their funds efficiently and effectively, whether the funds collected from the public, the owner or founder of the capital funds of Islamic banks as well as on the use or cultivation of these funds.

Banks that have a good level of capital adequacy shows indicators of healthy banks because capital adequacy indicates the state represented by the capital adequacy ratio (CAR) which is measured by comparing the capital to risky assets (Rachmadi Usman, 2001: 106107). In analyzing the risk-weighted assets in Islamic banks, formerly considered that the assets of Islamic banks that can be divided on the assets financed by own capital or liabilities, or assets financed by profit sharing accounts.

The capital adequacy ratio (CAR) can be formulated as follows:

$$
\text { CAR } \frac{\text { Modal Bank }}{\text { Aktiva Tertimbang Menurut Resiko }} \times 100 \%
$$

\section{Definition of Liquidity}

Liquidity is the ability of a person or company to meet the obligations or debt that must be paid immediately with the smooth treasure (Ridwan Tobing dan Bill Nikholaus, 2003: 124). In the world of banking, liquidity management is the ability of banks to provide sufficient funds to meet its obligations at any time. Islamic bank is said to be liquid if: (a) it can maintain Statutory Reserves at Bank Indonesia in accordance with applicable regulations, (B) if can maintain giro at correspondent banks. Giro is an account maintained in correspondent banks as determined by the minimum balance, $(C)$ if it can maintain a sufficient cash to fulfill cash withdrawal (Muhammad, 2007: 66). Liquidity ratio analysis in this study using a calculation Financing to Deposit Ratio (FDR) or in a conventional bank is also called the Loan to Deposit Ratio (LDR) which is a ratio to measure the bank's ability to meet its obligations derived from the demand for financing.

The higher the ratio of FDR, the lower the ability of the bank's liquidity. Maximum FDR magnitude according to government regulations is $110 \%$ (Kasmir, 2003:272). The formula used is:

$$
\mathrm{FDR}=\frac{\text { Total Pembiayaan yang Diberikan }}{\text { Total DPK dan Ekuitas }} \times 100
$$

\section{Definition of Operational Efficiency}

A Bank is categorized to be efficient depending on how its management processes the input into output. Efficiency of banking should be done in order to optimize the existing input in order to produce the maximum output. Input on Islamic banking is composed of three, namely: (1) the funds of investors and shareholders, (2) derived from lending financial institutions (bank and non-bank) and loans from Bank Indonesia, and (3) deposits, savings and time deposits. After the input collected at the bank, then Islamic banks can generate output distribution of funds in the form of financing and services. ROA is used to measure the efficiency and ability of banks to carry out operations (Lukman Dendawijaya, Lukman. 2009: 119). BOPO is calculated by the following formula: 


$$
\mathrm{BOPO}=\frac{\text { Beban Operasional }}{\text { Pendapatan Operasional }} \times 100 \%
$$

\section{Profitability}

In this study the profitability will be proxied by the ROA as a measure of banking performance. ROA is used to analyze the level of profitability by comparing net income to total assets (Muhammad, 2007: 146). ROA in Islamic banking formulated as follows: (Rivai, Veithzal dan Arifin, Arvian, 2010: 866)

$$
\text { ROA }=\frac{\text { Laba Sebelum Pajak }}{\text { Total Aktiva }} \times 100 \%
$$

This implies that the larger the ROA, the greater the profit level achieved and the better the position of the bank in terms of asset utilization. Conversely, the smaller the ROA describe poor performance of banks in managing assets to generate earnings.

\section{Effect of Capital Adequacy Ratio (CAR) to Profitability (ROA)}

CAR reflects the equity capital of the company. This shows that the greater the $\mathrm{CAR}$, the greater the chance of the bank in generating profits, because of the large capital, the bank's management is very flexible to place their funds into investment activities profitable and reflects the bank's ability to bear risks that may arise and show versatility in anticipation of a decline in assets that customer funds are protected and increase public confidence. Therefore, compliance with capital adequacy ratio (CAR) that must be provided by the bank become important to measure in order to maintain the security of funds, especially owners of public funds against the possibility of losses from investments in property (Zainul Arifin, 2005: 135). The additional capital may also reduce the profitability, if the bank implanting them in the form of unproductive assets or implanting them in productive assets but does not use the precautionary principle (investment income) so it will not bring cash flow to the fullest. Thus, the bank's profit will remain or even fall and cause ROA down anyway.

\section{Effect of Liquidity (FDR) to Profitability (ROA)}

FDR is the size of liquidity that measure the amount of funds placed in the form of credit from the funds collected by the bank (especially public funds). The higher FDR showed that the more risky liquidity conditions of banks and the higher funds channeled to third parties so that the earnings (ROA) of banks will increase. On the contrary, if lower FDR indicate less effectiveness bank in the finance portfolio, but if it is not able to restore some of its obligations when the bank will lose the confidence of customers to partner with the bank. This, in turn, may also reduce the profitability (ROA).

\section{Effect of Operational Efficiency (BOPO) to Profitability (ROA)}

The end result of the bank's activities will generate costs as well as operating income. Both of these affect the level of operational efficiency that is the bank's ability to generate profits from the use of assets in order to cover the operational costs. In other words, the more efficient operating costs, the more efficient in the use of assets to generate profits. The lower the level of BOPO ratio means the better the performance of the bank's management and the higher levels of operational efficiency that is more efficient bank in generating profits as indicated by the increased profitability (ROA), due to 
more efficient use of existing resources in the company. In contrast, the high BOPO ratio reflects the operational inefficiencies which characterized by high operating expenses and will result in less income and lower ROA. However, if the increase in the bank's operational costs coupled with the increase in operating income is bigger, it will affect the increase in ROA.

\section{DATA ANALYSIS AND DISCUSSION}

Data CAR, FDR, ROA and ROA of PT. Bank Syariah Mandiri during the period of 2008 s.d. in 2015 that were obtained from the quarterly financial statements published by PT. Bank Syariah Mandiri were as follows:

Table 2. (CAR PT. Bank Syariah Mandiri Period of 2008 s.d. 2015)

\begin{tabular}{|c|c|c|c|}
\hline No & Criteria & Amount & Percentage \\
\hline 1 & Healthy $\quad: \geq 8 \%$ & 31 & $100 \%$ \\
\hline 2 & Healthy enough $: \geq 6,5 \%-<8,0 \%$ & 0 & $0 \%$ \\
\hline 3 & Not healthy $\quad:>6,5 \%$ & 0 & $0 \%$ \\
\hline & Total & 31 & $100 \%$ \\
\hline
\end{tabular}

Source: www.banksyariahmandiri.co.id (processed)

Table 3. (FDR PT. Bank Syariah Mandiri Period of 2008 s.d. 2015)

\begin{tabular}{|c|c|c|c|}
\hline No & Criteria & Amount & Percentage \\
\hline 1 & Healthy $\quad: \leq 94,75 \%$ & 29 & $94 \%$ \\
\hline 2 & Healthy enough $: \geq 94,75 \%-\leq 98,70 \%$ & 1 & $3 \%$ \\
\hline 3 & Unwell $\quad: \geq 98.50-\leq 102,25 \%$ & 1 & $3 \%$ \\
\hline 4 & Not healthy & 0 & 0 \\
\hline & Total & 31 & $100 \%$ \\
\hline
\end{tabular}

Source: www.banksyariahmandiri.co.id (processed)

Table 4. (BOPO PT. Bank Syariah Mandiri Period of 2008 s.d. 2015)

\begin{tabular}{|c|c|c|c|}
\hline No & Criteria & Amount & Percentage \\
\hline 1 & Healthy $\quad: \leq 93,52 \%$ & 28 & $90 \%$ \\
\hline 2 & Healthy enough $:>93,52 \%-\leq 94,72 \%$ & 0 & 0 \\
\hline 3 & Unwell $\quad:>94,72-\leq 95,92 \%$ & 0 & 0 \\
\hline \multirow[t]{2}{*}{4} & Not healthy & 3 & $10 \%$ \\
\hline & Total & 31 & $100 \%$ \\
\hline
\end{tabular}

Source: www.banksyariahmandiri.co.id (processed)

Table 5. (ROA PT. Bank Syariah Mandiri Periode 2008 s.d. 2015)

\begin{tabular}{|c|c|c|c|}
\hline No & Criteria & Amount & Percentage \\
\hline 1 & Healthy & 25 & $81 \%$ \\
\hline 2 & Healthy enough $: \geq 0,99 \%-<1,22 \%$ & 0 & 0 \\
\hline 3 & Unwell $\quad: \geq 0,77 \%-<0,99 \%$ & 1 & $3 \%$ \\
\hline 4 & Not healthy & 5 & $16 \%$ \\
\hline & Total & 31 & $100 \%$ \\
\hline
\end{tabular}

Source: www.banksyariahmandiri.co.id (processed) 

From the table above shows that during the study period CAR PT. Bank Syariah Mandiri relatively healthy with a total of 31 observation period and the percentage contribution of $100 \%$. This shows that the capital of PT. Bank Syariah Mandiri during the study period were able to offset a decline in its assets as a result of bank losses caused by risky assets on a monthly basis. While FDR of PT. Bank Syariah Mandiri categorized as healthy from 29 observation period and the percentage contribution of $94 \%$ remainder is fairly sound one period and one period of less healthy with their respective percentage of $3 \%$. This indicates that PT. Bank Syariah Mandiri is able to compensate for the provision of financing to customers who require cost by the demand of depositors who want to withdraw the money that has been used by banks to provide financing, so the bank can immediately settle their obligations that must be paid when billed by depositors by $94 \%$.

BOPO ratio of PT. Bank Syariah Mandiri in the period of 2008 up to 2015 relatively healthy with a total of 28 observation period and the percentage contribution of $90 \%$ of the 31 period. While the three other periods classified as unhealthy by $10 \%$. This shows that the performance of the management of PT. Bank Syariah Mandiri in the study period was good, because the more efficient use of existing resources in the company. Furthermore, ROA of PT. Bank Syariah Mandiri included in the healthy category by the number of periods and contribute as much as 25 percentage of $81 \%$, the rest is classified as less healthy first period with a percentage of $3 \%$ and 5 periods of relatively unhealthy with a percentage of $16 \%$. This suggests that the ability of the management of PT. Bank Syariah Mandiri in gain (profit) overall good. The greater the ROA of a bank, the greater the profit level reached the bank, the better the position of the bank in terms of asset utilization.

\section{Multiple Regression Analysis}

Multiple regression model used in this study to determine the effect of independent variables namely CAR, FDR and BOPO the dependent variable is profitability (ROA) at PT. Bank Syariah Mandiri for the period 2008 s.d. 2015. Multiple regression analysis performed using SPSS, the following regression processed results obtained:

\section{Table 6. (Multiple Regression Analysis) Coefficients}

\begin{tabular}{|c|c|c|c|}
\hline \multirow{2}{*}{\multicolumn{2}{|c|}{ Model }} & \multicolumn{2}{|c|}{ Unstandardized Coefficients } \\
\hline & & B & Std. Error \\
\hline \multirow[t]{4}{*}{1} & (Constant) & 6.818 & .763 \\
\hline & CAR & -.033 & .021 \\
\hline & FDR & .009 & .007 \\
\hline & BOPO & -.068 & .004 \\
\hline
\end{tabular}

a. Dependent Variable: ROA 
Based on the results of multiple regression analysis model is obtained the following regression equation: $\mathrm{Y}=6.818$ $0.033 \times 1+0.009 \times 2-0.068 \times 3$

Interpretation of regression functions above are as follows:

1. Value or constant $a=6.818$ shows that if the value of CAR, FDR and ROA is zero then the value of $\mathrm{Y}$ profitability (ROA) was 6.818. Value of 0.763 is the magnitude of the standard error of regression function constants.

2. CAR variable regression coefficient value $(\mathrm{X} 1)$ of -0.033 , variable FDR $(\mathrm{X} 2)$ of 0.009 , the variable $\mathrm{BOPO}(\mathrm{X} 3)=-$ 0.068 , indicating that every increase in CAR, FDR, BOPO of $1 \%$, the profitability will be decreased by 0,033 $\%$, for CAR, and $0.068 \%$ for $\mathrm{BOPO}$, while FDR increased by 0,009\%, assuming other variables held constant (ceteris paribus). So CAR and $\mathrm{BOPO}$ have a negative impact While (FDR) have positive influence on profitability at PT. Bank Syariah Mandiri for the period 2008 s.d. 2015.

Table 7. (Test Results Significance Partial (T test)) Coefficients

\begin{tabular}{|c|c|c|c|c|c|c|}
\hline \multirow{2}{*}{\multicolumn{2}{|c|}{ Model }} & \multicolumn{2}{|c|}{ Unstandardized Coefficients } & \multirow{2}{*}{$\begin{array}{c}\text { Standardized } \\
\text { Coefficients }\end{array}$} & \multirow[b]{2}{*}{$\mathrm{t}$} & \multirow[b]{2}{*}{ Sig. } \\
\hline & & $\mathrm{B}$ & Std. Error & & & \\
\hline \multirow[t]{4}{*}{1} & (Constant) & 6.818 & .763 & & 8.938 & .000 \\
\hline & CAR & -.033 & .021 & -.074 & -1.574 & .127 \\
\hline & FDR & .009 & .007 & .058 & 1.194 & .243 \\
\hline & BOPO & -.068 & .004 & -.933 & -18.922 & .000 \\
\hline
\end{tabular}

Dependent Variable: ROA

CAR $t$ test result variable (X1) obtained by the $t$ calculate equal to -1.574 and significance of $0.127>a=5 \%(0.05)$, while the value $\mathrm{t}$ table amounted to -1.703 , then $t(-1.574)>t$ table $(-1.703)$, so that $\mathrm{Ha}$ is accepted and $\mathrm{HO}$ is rejected. Further to FDR variable $(\mathrm{X} 2)$ obtained by the $t$ count equal to 1.194 and a significance of $0.243>$ $\mathrm{a}=5 \%(0.05)$, while the value $\mathrm{t}$ table amounted to 1.703 , then the $\mathrm{t}(1.194<\mathrm{t}$ table (1.703), so that $\mathrm{Ha}$ is rejected and $\mathrm{HO}$ is accepted. It can be concluded that partial CAR and no significant negative effect on profitability (ROA) while FDR was positive and no significant effect on profitability (ROA) at PT. Bank Syariah Mandiri for in the period of 2008 s.d. 2015.

The results of the $t$ test variable BOPO (X3) obtained $t$ count equal -18.922 results and significance of $0.000<\alpha=5 \%$ (0.05), while the value $t$ table amounted to -1.703 , then $\mathrm{t}(-18.922<\mathrm{t}$ table $(-1.703)$, so that $\mathrm{Ha}$ is rejected and $\mathrm{H} 0$ is accept. It can be concluded that partially BOPO no negative effect and significant on profitability (ROA) at PT. Bank Syariah Mandiri for the period of 2008-2015. This means that the greater the value of $\mathrm{BOPO}$, the smaller the level of profitability generated by the bank. 
52 || Jurrnal Ilmiah Sygari'ah, Volume Iis, Nomor I, Jantuari-Juni 20016

Table 8. (Simultaneous Test Results Significance (F test))

ANOVA ${ }^{b}$

\begin{tabular}{|ll|r|r|r|r|r|}
\hline Model & & Sum of Squares & Df & Mean Square & F & Sig. \\
\hline 1 & Regression & 11.651 & 3 & 3.884 & 156.817 & $.000^{\mathrm{a}}$ \\
& Residual & .669 & 27 & .025 & & \\
& Total & 12.319 & 30 & & & \\
\hline
\end{tabular}

a. Predictors: (Constant), BOPO, CAR, FDR

b. Dependent variable ROA

From the research that calculated $\mathrm{F}$ value of 156.817 with $\mathrm{F}$ tables of 2.96 , so that $\mathrm{F}$ count $>\mathrm{F}$ table $(156.817>2.96)$ with significant value $0,000<\alpha=5 \%(0.05)$. This means that there is significant influence jointly between all independent variables (CAR, FDR and BOPO) on the dependent variable (ROA) at PT. Bank Syariah Mandiri for the period 2008 s.d. 2015.

\section{The coefficient of determination (R2)}

From the results of the calculation, the coefficient of determination as follows:

Table 9. (Coefficient of determination (R2)

\begin{tabular}{|l|c|r|r|r|c|}
\hline Model & \multicolumn{1}{|c|}{$\mathrm{R}$} & $\mathrm{R}$ Square & $\begin{array}{l}\text { Adjusted R } \\
\text { Square }\end{array}$ & $\begin{array}{l}\text { Std. Error of } \\
\text { the Estimate }\end{array}$ & $\begin{array}{l}\text { Durbin- } \\
\text { Watson }\end{array}$ \\
\hline 1 & $.972^{\mathrm{a}}$ & .946 & .940 & .15737 & 1.527 \\
\hline
\end{tabular}

Based on the results obtained from the regression of the table shows that the value of $R$ Square is 0.946 , meaning that $94.6 \%$ of profitability (ROA) can be explained by the variables of CAR, FDR and $\mathrm{BOPO}$, while the rest $(100 \%-94.6 \%=$ $5,4 \%)$ is explained by other variables which was not examined in this study.

\section{CONCLUSION}

Based on the results of research and discussion, it can be conclude several things, as follows:

1. Results of the $t$ test for variable CAR (X1) obtained results partially, CAR has negative effect and not significant to profitability (ROA), while the variable FDR (X2) partially has no positive effect and not significant to profitability (ROA) at PT. Bank Syariah Mandiri for the period 2008-2015. While variable BOPO (X3) obtained result partially has negative effect and signifacant to profitability (ROA) at PT. Bank Syariah Mandiri for the period 2008-2015. This means greater the value of $\mathrm{BOPO}$, the smaller the level of profitability generated by the bank.

2. CAR, FDR and BOPO simultaneously have a significant impact on profitability (ROA) at PT. Bank Syariah Mandiri for the period 2008 s.d. 2015. 


\section{SUGGESTION}

As for suggestions:

1. Referring to the results of research, independent Islamic banks should further enhance the distribution of funding to the productive unit or community to gain share of revenue and profitability (profit) increases.

2. For subsequent researchers, is expected to add other financial ratios as independent variables that affect the profitability, because it is possible other financial ratios that are not included in this study affect the profitability.

\section{LIST OF REFERENCES}

Afif, Faisal, dkk. 2003. Strategi dan Operasional bank, Bandung: Eresco,

Arifin, Zainul. 2005. Dasar-dasar Manajemen Bank Syariah, Jakarta: Pustaka Alvabet.

Ariyani, Desi, "Analisis Pengaruh CAR, FDR, BOPO, dan NPF terhadap Profitabilitas PT. Bank Muamalat Indonesia Tbk (Januari 2005- April 2008)“", skripsi dipublikasikan. Jurusan Perbankan Syariah Fakultas Syariah dan Hukum UIN Syarif Hidayatullah Jakarta, 2009, http:// repository.uinjkt.ac.id

Arikunto, Suharsimi. 2010. Prosedur Penelitian Suatu Pendekatan Praktik, Jakarta: Rineka Cipta.

Arthesa, Ade dan Handiman, Edia. 2006. Bank dan Lembaga Keuangan Bukan Bank. Jakarta: INDEKS.

Dendawijaya, Lukman. 2009. Manajemen Perbankan, Jakarta: Ghalia Indonesia.

Fahmy, M. Shalahuddin, "Pengaruh CAR, NPF, BOPO dan FDR terhadap
Profitabilitas Bank Umum Syariah", skripsi dipublikasikan. Program Studi Keuangan Islam Fakultas Syariah dan Hukum Universitas Islam Negeri Sunan Kalijaga, 2013, http:/ / digilib.uin-suka.ac.id/akses pada pada 21 september 2014.

Gandrapradja, Permadi. 2004. Dasar dan Prinsip Pengawasan Bank, Jakarta: Gramedia Pustaka Utama.

Indriantoro, Nur dan Supomo, Bambang. 1999. Metodologi Penelitian Bisnis untuk Akuntansi dan Manajemen. edisi 1, Yogyakarta: BPFE.

Karim, Adiwarman. 2004. Bank Islam Analisia Fiqih dan Keuangan, Jakarta: Raja Garfindo.

Kasmir. 2003. Manajemen Perbankan, Jakarta: Rajawali Press.

Latumaerissa, Julius R. 2005. Mengenal Aspek-aspek Operasi Bank Umum, Jakarta: Bumi Aksara.

Muhammad. 2007. Manajemen Dana Bank Syariah, Yogyakarta: Ekonesia.

Muhamad, 2008. Metode Penelitian Ekonomi Islam Pendekatan Kuantitatif, Jakarta: Raja Grafindo Persada.

Muljono, Teguh Pudjo. 1986. Analisa Laporan Keuangan untuk Perbankan, Jakarta: Jambatan Anggotaa IKPI.

Muslich, Muhammad. 2003. Manajemen Keuangan Modern: Analisis, Perencanaan dan Kebijaksanaan Jakarta: Bumi Aksara, cet. 3 .

Rochaety, Ety, dkk. 2007. Metodologi Penelitian Bisnis dengan Aplikasi SPSS, Jakarta: Mitra Wacana Media. 
54

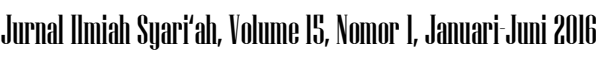

Rivai, Veithzal dan Arifin, Arvian. 2010. Islamic Banking: Sebuah Teori, Konsep, dan Aplikasi,Jakarta: Bumi Aksara.

Riyadi, Selamet. 2006. Banking Assets and Liability Manajement, Jakarta: Fakultas Ekonomi Universitas Indonesia.

Riyanto, Bambang. 2001. Dasar-dasar Pembelanjaan Perusahaan, edisi 4, Yogyakarta: BPFE.

Siamat, Dahlan. 2007. Manajemen Lembaga Keuangan, Jakarta: FEUI.

Simorangkir. 2004. Pengantar Lembaga Keuangan Bank dan Nonbank, cet.2, Bandung: Ghalia Indonesia.

Suhirman. 2001. Kajian tentang Perkembangan LDR dan Dampaknya bagi Rentabilitas Bank, Jakarta: Institut Bankir Indonesia.
Sugiyono. 2007. Metode Penelitian Bisnis, Bandung: Alfabeta,

Suryani, Analisis Pengaruh Financing to Deposit Rasio (FDR) terhadap Profitabilitas

Perbankan di Indonesia, STAIN Malikussaleh Lhokseumawe, Walisongo, Volume 19, Nomor 1. Mei 2011,

Tobing, Ridwan dan Nikholaus, Bill. 2003. Kamus Istilah Perbankan Populer, Jakarta: Atalya Releni Sudeco.

Usman, Rachmadi. 2001. Aspek-aspek Hukum Perbankan di Indonesia, Jakarta: Gramedia Pustaka Utama. 